\title{
Penerapan Tata Tertib Sekolah untuk Membangun Disiplin Siswa di SMA Negeri 1 Konawe
}

Saidah Laugi

Dinas Pendidikan dan Kebudayaan Kabupaten Konawe email: saidahlaugi78@gmail.com

\begin{abstract}
Abstrak
Artikel ini bertujuan memberikan gambaran tentang: 1) Penerapan tata tertib sekolah di SMA Negeri 1 Konawe; 2) Kedisiplinan siswa di SMA Negeri 1 Konawe; 3) Strategi penerapan tata tertib sekolah dalam rangka membangun disiplin siswa di SMA Negeri 1 Konawe. Penelitian ini merupakan penelitrian kualitatifdeskriptif, yang dalam pengumpulan data menggunakan teknik wawancara, pengamatan, dan telaah dokumen. Analisis data melalui tahap reduksi, display, dan penarikan kesimpulan. Hasil penelitian menunjukkan bahwa: 1) Penerapan tata tertib sekolah merupakan langkah strategis yang diambil sebagai panduan warga sekolah dalam berperilaku di lingkungan sekolah; 2) Kedisiplinan siswa di SMA Negeri 1 Konawe menunjukkan kecenderungan yang bervariasi, disebabkan oleh kondisi lingkungan sekolah dan variasi latar belakang siswa; 3) Strategi penerapan tata tertib sekolah dilakukan dengan sosialisasi pada orang tua murid dan masyarakat, melibatkan organisasi siswa intra sekolah (OSIS), gerakan pramuka, serta menggiatkan perkumpulan olah raga siswa.
\end{abstract}

Kata Kunci: Tata Tertib, Disiplin, Budaya Sekolah 


\title{
Implementation of School Rules for Building Student Discipline in SMA Negeri 1 Konawe
}

\author{
Saidah Laugi \\ Dinas Pendidikan dan Kebudayaan Kabupaten Konawe \\ email: saidahlaugi78@gmail.com
}

\begin{abstract}
This article aims to provide an overview of: 1) Application of school rules in SMA 1 Konawe; 2) Discipline of students in SMA Negeri 1 Konawe; 3) Strategies for implementing school rules in order to build student discipline in Konawe 1 High School. This research is a qualitative-descriptive research, which in data collection uses interview, observation, and document review techniques. Data analysis through the stages of reduction, display, and drawing conclusions. The results showed that: 1) The application of school rules is a strategic step taken as a guide for school residents to behave in the school environment; 2) Discipline of students in SMA Negeri 1 Konawe shows a tendency to vary, caused by the condition of the school environment and variations in student backgrounds; 3) The strategy for implementing school rules is carried out with socialization to students' parents and the community, involving intra-school student organizations (OSIS), scouting movements, and intensifying student sports associations.
\end{abstract}

Keywords: Order, Discipline, School Culture

\section{Latar Belakang}

Secara makro, pendidikan adalah upaya mencerdaskan kehidupan bangsa dan meningkatkan kualitas sumber daya manusia untuk mencapai Indonesia yang adil, makmur, dan maju ${ }^{1}$. Peserta didik sebgai sumber daya manusia masa depan bangsa perlu disiapkan untuk menjawab harapan-harapan tersebut. Caranya adalah melalui penciptaan kondisi sekolah yang memadai untuk tumbuh kembang peserta didik secara paripurna. Salah satunya adalah merancang

1 Indonesia, U. U. R. (2003). Sistem pendidikan nasional. Jakarta: Direktorat Pendidikan Menengah Umum. 
peraturan-peraturan yang dapat menjamin berlangsungnya kegiatan pembelajaran yang sesuai harapan. Tanpa peraturan, tidak hanya siswa, tetapi guru juga dapat menampakkan perilaku yang tidak sejalan dengan norma-norma pendidikan dan pembelajaran. Karenanya disiplin sangat perlu dalam proses belajar mengajar. Alasannya yaitu : disiplin dapat membantu kegiatan belajar, dapat menimbulkan rasa senang untuk belajar dan meningkatkan hubungan sosial $^{2}$.

Sekolah dapat membuat kebijakan tertentu dalam bentuk aturan. Salah satunya tata tertib sekolah, dimana siswa mempedomani tata tertib sekolah itu dalam rangka keberhasilan proses belajar mengajar, dan membentuk karakteristik siswa agar disiplin dan bertanggung jawab. Peraturan sekolah tersebut di buat untuk mendidik kedisiplinan, mempengaruhi, mendorong, mengendalikan, mengubah, membina, dan membentuk perilaku siswa sesuai dengan nilai-nilai yang ditanamkan. Penanaman nilai disiplin dan tanggunga jawab pada diri siswa di sekolah akan mereka bawa dilingkungan sekitar, baik itu dalam keluarga maupun lingkungan sosial masyarakat secara luas ${ }^{3}$.

Peserta didik adalah anggota masyarakat yang berusaha mengembangkan potensi diri melalui proses pembelajaran yang tersedia pada jalur, jenjang dan jenis pendidikan tertentu ${ }^{4}$. Siswa terlibat langsung dalam dunia pendidikan, melalui sekolah siswa mendapatkan pendidikan dengan berlangsungnya proses pembelajaran. Proses pembelajaran dapat berlangsung di dalam kelas atupun di luar kelas dengan bimbingan seorang guru. Melalui pendidikan siswa belajar untuk mengenal diri, belajar mengenal orang lain, dan belajar mengenal lingkungan sekitarnya.

Disiplin (discipline) berasal dari bahasa berarti kepatuhan atau yang menyangkut tata tertib. Istilah disiplin dalam Bahasa Indonesia

${ }^{2}$ Hadianti, L. S. (2017). Pengaruh Pelaksanaan Tata Tertib Sekolah Terhadap Kedisiplinan Belajar Siswa (Penelitian Deskriftif Analisis di SDN Sukakarya II Kecamatan samarang Kabupaten Garut). Jurnal Pendidikan UNIGA, 2(1), 1-8.

${ }^{3}$ Trisnawati, D. D. (2013). Membangun Disiplin dan Tanggung Jawab Siswa SMA Khadijah Surabaya melalui Implementasi Tata Tertib Sekolah. Kajian Moral dan Kewarganegaraan, 2(1), 397-411.

${ }^{4}$ Indonesia, P. R. (2006). Undang-undang Republik Indonesia nomor 20 tahun 2003 tentang sistem pendidikan nasional. 
kerapkali terkait dan menyatu dengan tata tertib dan ketertiban. Istilah ketertiban mempunyai arti kepatuhan seseorang dalam mengikuti peraturan atau tata tertib karena di dorong atau disebabkan oleh suatu yang datang dari luar dirinya. Disiplin sebagai kepatuhan dan ketaatan yang muncul karena adanya kesadaran dan dorongan dari dalam diri sendiri. Tata tertib berarti seperangkat peraturan yang berlaku untuk menciptakan kondisi yang tertib dan teratur ${ }^{6}$.

Kepatuhan dan ketaatan siswa terhadap berbagai aturan dan tata tertib yang berlaku di sekolahnya itu bisa disebut dengan disiplin siswa. Sedangkan peraturan, tata tertib dan berbagai ketentuan lainnya yang bertujuan mengatur perilaku siswa disebut disiplin sekolah. Disiplin sekolah adalah usaha sekolah untuk memelihara perilaku siswa agar tidak menyimpang dari aturan dan dapat mendorong siswa untuk berperilaku yang sesuai dengan norma, peraturan dan tata tertib yang berlaku disekolah ${ }^{7}$.

Pengendalian diri harus dikembangkan pada siswa, yaitu kondisi dimana seseorang dalam perbuatannya selalu dapat menguasai diri sehingga tetap mengontrol dirinya dari berbagai keinginan yang terlalu berlebihan. Pengendalian diri tersebut terkandung keteraturan hidup dan kepatuhan akan segala peraturan, dengan kata lain perbuatan siswa selalu berada dalam koridor disiplin dan tata tertib sekolah. Maka hal tersebut akan menumbuhkan rasa kedisiplinan siswa untuk mengikuti tiap peraturan yang berlaku di sekolah ${ }^{8}$.

Penelusuran penulis di SMAN 1 Konawe, peneliti menemukan beberapa fakta yaitu; terlihat bahwa di SMAN 1 Konawe memiliki lingkungan sekolah yang sangat luas namun tidak memiliki pagar pembatas, sehingga membuat siswa mudah untuk keluar masuk dari lingkungan sekolah. Dalam proses belajar mengajar sedang

${ }^{5}$ Hendra, V. (2018). Peran Orang Tua Dalam Menerapkan Kasih Dan Disiplin Kepada Anak Usia 2-6 Tahun Sebagai Upaya Pembentukkan Karakter. KURIOS (Jurnal Teologi dan Pendidikan Agama Kristen), 3(1), 48-65.

${ }^{6}$ Ningsih, B. M., \& Widiharto, C. A. (2014). Peningkatan Disiplin Siswa dengan Layanan Informasi Media Film. EMPATI-Jurnal Bimbingan dan Konseling, l(1/oktober).

${ }^{7}$ Roshita, I. (2014). Meningkatkan Kedisiplinan Siswa Melalui Layanan Bimbingan Kelompok dengan Teknik Modeling. Jurnal Penelitian Tindakan Kelas, 15(4).

8 Ariananda, E. S., Hasan, S., \& Rakhman, M. (2014). Pengaruh kedisiplinan siswa di sekolah terhadap prestasi belajar siswa teknik pendingin. Journal of Mechanical Engineering Education, 1(2), 233-238. 
berlangsung beberapa siswa sengaja keluar untuk tidak mengikuti pelajaran yang sedang berlangsung. Pada saat proses belajar mengajar sedang berlangsung beberapa siswa asik berdiskusi sendiri dengan teman-temannya. Adapula guru yang membawa kegiatan rumah tangga di kantor. Seharusnya kegiatan ini tidak dilakukan di dalam lingkungan sekolah apa lagi di dalam kantor tempat dimana semua guru berkumpul dan membicarakan hal-hal yang berkaitan dengan pendidikan, bagaimana seharus nya proses belajar mengajar yang harus dilakukan oleh seorang guru. Fakta lainnya adalah kurangnya media pembelajaran dengan teknologi terkini yang akan digunakan dalam proses belajar mengajar, menjadi faktor lain yang menyumbangkan rendahnya disiplin siswa

\section{Berbagai Aspek Disiplin Siswa}

Disiplin berasal dari bahasa latin "Disciplina" yang menunjuk kepada kegiatan belajar mengajar. Istilah tersebut sangat dekat dengan istilah dalam bahasa inggris "disciple" yang berarti mengikuti orang untuk belajar dibawah pengawasan seorang pemimpin ${ }^{9}$. Disiplin dapat dikatakan sebagai kondisi yang tercipta dan terbentuk melalui ketaatan, kepatuhan, keteraturan, atau ketertiban. Nilai-nilai tersebut telah menjadi bagian perilaku dalam kehidupannya. Perilaku itu tercipta melalui proses binaan melalui keluarga, pendidikan, dan pengalaman $^{10}$.

Fungsi-fungsi disiplin antara lain: menata kehidupan bersama, membangun kepribadian, melatih kepribadian, pemaksaan, dan hukum ${ }^{11}$. Disiplin berguna untuk menyadarkan seseorang bahwa dirinya perlu menghargai orang lain dengan cara menaati dan mematuhi peraturan yang berlaku. Ketaatan dan kepatuhan itu membatasi dirinya agar tidak merugikan pihak lain, tetapi hubungan dengan sesama menjadi lebih baik dan lancar. Kepribadian adalah

9 Ardini, P. P. (2015). "Penerapan Hukuman”, Bias Antara Upaya Menanamkan Disiplin Dengan Melakukan Kekerasan Terhadap Anak. Jurnal Pendidikan Usia Dini, 9(2), 251-266.

${ }^{10}$ Prasetyo, P. E. (2008). Pengaruh disiplin siswa dan fasilitas perpustakaan sekolah terhadap prestasi belajar siswa mata pelajaran ekonomi. Dinamika Pendidikan, 3(2).

${ }^{11}$ Nansi, D., \& Utami, F. T. (2016). Hubungan antara Regulasi Emosi dengan Perilaku Disiplin Santri Madrasah Aliyah Pondok Pesantren Qodratullah Langkan. Psikis: Jurnal Psikologi Islami, 2(1). 
keseluruhan sifat, tingkah laku dan pola hidup seseorang tercermin dalam penampilan, perkataan dan perbuatan sehari-hari. Lingkungan yang berdisiplin baik, sangat berpengaruh terhadap kepribadian seseorang. Apalagi siswa yang sedang tumbuh kepribadiannya, tertentu lingkungan sekolah yang tertib, teratur, tenang, tentram, sangat berperan dalam membangun kepribadian yang baik. Sikap, perilaku dan pola kehidupan yangbaik dan berdisiplin tidak terbentuk serta-merta dalam waktu singkat. Namun, terbentuk melalui proses yang membutuhkan waktu panjang. Salah satu proses untuk membentuk kepribadian tersebut dilakukan melalui latihan. Disiplin dapat pula terjadi karena adanya pemaksaan dan tekanan dari luar. Disiplin yang terpaksa, bukan karena kasadaran diri, akan memberi pengaruh kurang baik. Tata tertib sekolah biasanya berisi hal-hal yang positif yang harus dilakukan oleh siswa. Sisi lainnya berisi sanksi atau hukuman bagi yang melanggar tata tertib tersebut. Tata tertib yang sudah disusun dan dilaksanakan seharusnya diikuti dengan penerapan secara konsisten dan konsekuen. Siswa yang melanggar peraturan yang berlaku harusdiberisanksi disiplin. Tanpa sanksi disiplin yang konsisten dan konsekuen akan membingungkan, memunculkan ketidakpuasan dan rasa ketidakadilan bagi yang disiplin ${ }^{12}$. Hukuman yang sifatnya mendidik inilah yang diperlukan dalam pendidikan. Kesalahan anak didik karena melanggar disiplin dapat diberi hukuman berupa sanksi menyapu lantai, mencatat bahan pelajaran yang ketinggalan, atau apa saja yang penting sifatnya mendidik. Menurut tujuan hukuman dimaksudkan untuk mengurangi banyaknya perilaku yang menyimpang dengan cara memberikan sesuatu yang menyebabkan siswa yang melakukan pelanggaran menjadi jera dan tidak mengulangi kesalahannya lagi ${ }^{13}$.

Dodson menyebutkan lima faktor penting dalam pembentukan disiplin anak yaitu:

1. Latar belakang dan kultur kehidupan keluarga. Bila orang tua sejak dari kecil terbiasa hidup dalam lingkungan yang keras, pemabuk, tidak memiliki disiplin, tidak menghargai orang lain, bertingkah

12 Nansi, D., \& Utami, F. T. (2016). Hubungan antara Regulasi Emosi dengan Perilaku Disiplin Santri Madrasah Aliyah Pondok Pesantren Qodratullah Langkan. Psikis: Jurnal Psikologi Islami, 2(1).

${ }^{13}$ Prasetyo, P. E. (2008). Pengaruh disiplin siswa dan fasilitas perpustakaan sekolah terhadap prestasi belajar siswa mata pelajaran ekonomi. Dinamika Pendidikan, 3(2). 
laku semaunyya, maka kebiasaan itu akan terbawa ketika orang tua membimbing dan menanamkan disiplin pada anaknya.

2. Sikap dan karakter orangtua, Faktor ini sangat mempengaruhi caracara orang tua dalam mananamkan disiplin pada anaknya. Orang tua yang mempunyai watak otoriter, suka menguasai, selalu mengangap diri palingbenar dan tidak memperdulikan orang lain, akan cenderung membina disiplin anak-anaknya secara otoriter.

3. Latar belakangpendidikan dan status sosial ekonomi keluarga. Orang tua yang mengecap pendidikan menengah keatas dan memiliki status sosial ekonomi yang baik, dalam arti dapat memenuhi kebutuhan-kebutuhan pokok keluarga, seperti pangan, sandang, pemukiman, kesehatan, dan pendidikan dapat mengupayakan pendidikan dan pembentukan disiplin yang lebih terencana, sistematis, dan terarah, dibanding dengan keluarga yang mempunyai pendidikan rendah, dan secara ekonomi tidak mampu memenuhi kebutuhan hidup sehari-hari yang layak.

4. Keutuhan dan keharmonisan dalam keluarga, Sebuah keluarga cenderungtidak utuh secra struktural, yaitu salah satunya, ibu atau ayah tidak lagi bersama-sama dalam keluarga, akan memberi pengaruh negatif terhadap penanaman disiplin pada anak.

5. Cara- cara dan tipe perilaku parental, Yaitu perilaku orang tua dalam membimbing, mendidik dan menanamkan disiplin pada anaknya ${ }^{14}$.

Pearce menyebutkan empat faktor yangharus diperhatikan dalam mendisiplinkan anak yaitu sebagai berikut:

1. Kepribadian anak, Anak yang peka (sensitif) yang mudah resah, biasanya sangat respontive terhadap segala macam disiplin dan juga terhadap suasana hati orang lain. Orang tua tidak perlu banyak meninggikan suara atau bersikap keras.

2. Usia anak, Anak yang lebih kecil memerlukan disiplin yang sangat jelas dan langsung dengan tingkat pengendalian yang tinggi. Katakata yang digunakan hrus sederhana atau mudah dimengerti dan kekangan fisikdiperlukan. Anak yang lebih besar memerlukan jenis disiplin yang mendorong pengendalian diri dan tanggung jawab.

${ }^{14}$ Ningsih, B. M., \& Widiharto, C. A. (2014). Peningkatan Disiplin Siswa dengan Layanan Informasi Media Film. EMPATI-Jurnal Bimbingan dan Konseling, 1(1/oktober). 
3. Kepribadian orang tua. Kepribadian orangtua cenderung mempengaruhi cara menangani anak, tetapi yang penting tidak membiarkan pengaruh kepribadian orang tua menjadi terlalu besar.

4. Pengalaman disiplin anak. Salah satu hal yang paling mengejutkan sebagai orangtua adalah efek langgeng yang ditimbulkan oleh masa anak-anak terhadap diri orangtua. Anak akan mengerjakan hal yang sama seperti yang dilakukan orang tua terdahulu ${ }^{15}$.

Tu'u menyebutkan empat faktor yang memengaruhi dan membentuk disiplin yaitu mengikuti dan menaati aturan, kesadaran diri, alat pendidikan, dan hukuman ${ }^{16}$. Selain itu, faktor lainnya yang berpengaruh pada pembentukan disiplin adalah:

a. Teladan. Perbuatan dan tindakan lebih besar pengaruhnya dibandingkan dengan kata-kata. Karena itu, contoh dan teladan disiplin atasan, kepala sekolah dan guru-guru serta penata usaha sangat berpengaruh terhadap disiplin para siswa.

b. Lingkungan berdisiplin. Seseorang dapat juga dipengaruhi oleh lingkungan. Bila berada di lingkungan berdisiplin, seseorang dapat terbawa oleh lingkungan tersebut.

c. Latihan berdisiplin. Disiplin dapat dicapai dan dibentuk melalui proses latihan dan kebiasaan. Artinya, melakukan disiplin secara berulang-ulang dan membiasakannya dalam praktik- praktik disiplin sehari-hari ${ }^{17}$.

Menurut Hurlock agar disiplin mampu mendidik anak untuk dapat berperilaku sesuai dengan standar yang ditetapkan oleh kelompok sosial mereka, maka disiplin harus memiliki empat unsur pokok yaitu peraturan, hukuman, penghargaan, dan konsistensi ${ }^{18}$.

Peraturan adalah pola yang ditetapkan untuk tingkah laku, dimana pola tersebut ditetapkan oleh orang tua, guru atau teman

${ }^{15}$ Ningsih, B. M., \& Widiharto, C. A. (2014). Peningkatan Disiplin Siswa dengan Layanan Informasi Media Film. EMPATI-Jurnal Bimbingan dan Konseling, l(1/oktober).

${ }^{16}$ Lomu, L., \& Widodo, S. A. (2018, February). Pengaruh Motivasi Belajar dan Disiplin Belajar terhadap Prestasi Belajar Matematika Siswa. In Prosiding Seminar Nasional Pendidikan Matematika Etnomatnesia.

${ }^{17}$ Ningsih, B. M., \& Widiharto, C. A. (2014). Peningkatan Disiplin Siswa dengan Layanan Informasi Media Film. EMPATI-Jurnal Bimbingan dan Konseling, 1(1/oktober).

18 Apsari, F. (2013). Hubungan antara harga diri dan disiplin sekolah dengan perilaku bullying pada remaja (Doctoral dissertation, Universitas Muhammadiyah Surakarta). 
bermain. Tujuannya adalah untuk membekali anak dengan pedoman perilaku yang disetujui dalam situasi tertentu. Peraturan mempunyai dua fungsi yaitu : a) peraturan mempuanyai nilai pendidikan, sebab peraturan memperkenalkan pada anak perilaku yang disetujui anggota kelompok tersebut; b) peraturan membantu mengekang perilaku yang tidak diinginkan. Agar peraturan dapat memenuhi kedua fungsi tersebut, maka peraturan itu haruslah dapat dimengerti, diingat dan diterima oleh si anak. Anak kecil membutuhkan lebih banyak peraturan di bandingkan dengan yang besar, sejak menjelang remaja anak dianggap telah belajar apa yang diharapkan dari kelompok sosial mereka ${ }^{19}$.

Hukuman berasal dari kata kerja latin, punire, dan berarti menjatuhkan hukuman pada seseorang karena suatu kesalahan,perlawanan atau pelanggaran sebagai ganjaran atau pembalasan. Walaupun tidak dikatakan, namun tersirat bahwa kesalahan, perlawanan atau pelanggaran inisengaja, dalam arti bahwaorang itu mengetahui bahwa perbuatan itu salah tetapi tetap melakukannya. Tujuan jangka pendek dari menjatuhkan hukuman adalah untuk menghentikan tingkah laku yang salah. Sedangkan tujuan jangka panjangnya adalah untuk mengajar dan mendorong anak untuk menghentikan sendiri tingkah laku merekayang salah. Hukuman merupakan salah satu unsur kedisiplinan yang dapat digunakan untuk membuat anak berperilaku sesuai standar yang ditetapkan keompok sosial mereka. Menurut Schaefer ada tiga bagian besar bentuk hukuman yang dapat diberikan sesudah satu perbuatan salah. Bentuk hukuman tersebut adalah sebagai berikut; a) Membuat anak-anak itu melakukan suatu perbuatan yang tidak menyenagkan, b) mencabut hak anak dari suatu kegemaran atau suatu kesempatan yang enak c) menimpakan kesakitan berbentuk kejiwaan dan fisik terhadap anak. Bentuk hukuman yang popular di masyarakat adalah bentuk hukuman nomor tiga, yaitu hukuman fisik, seperti menempeleng, memukul, memecut dan lain-lain. Bentuk hukuman seperti ini dianggap efektif untuk mendisiplinkan anak. Bentuk hukuman fisik seperti itu dapat memunculkan dendam pada diri anak. Akibatnya ekspresi kejiwaan yang ditampilkan oleh anakakan muncul berupa sikap menantang atau

19 Apsari, F. (2013). Hubungan antara harga diri dan disiplin sekolah dengan perilaku bullying pada remaja (Doctoral dissertation, Universitas Muhammadiyah Surakarta). 
melawan, dan menifestasikan perilaku yang tampak adalah kekerasan, kebrutalan, merusak, bahkan melanggar hukum. Jadi hukuman yang berbentukfisik bagi anak yang terobsesi dendam tidak akan menyelesaikan masalah, namun justru akan menimbulkan masalah baru dimana iaakan tumbuj menjadi anak yang pembangkang ${ }^{20}$.

Penghargaan berarti tiap bentuk penghargaan untuk suatu hasil yang baik. Penghargaan tidak perlu berbentuk materi, tetapi dapat berupa kata-kata pujian, senyuman atau tepukan di punggung. Penghargaan mempunyai beberapa peranan penting dalam mengajar anak untuk berperilaku sesuai dengan cara yang direstui masyarakat yaitu: a) penghargaan mempunyai nilai mendidik, b) penghargaan sebagai motivasi untuk mengulangi perilaku yang disetujui secara sosial. Apapun bentuk penghargaan yang digunakan, penghargaan itu harus sesuai dengan perkembangan anak. Bila tidak, ia akan kehilangan efektifitasnya. Dengan meningkatkannya usia, penghargaan bertindak sebagai sumber motivasi yang kuat anak bagi anak untuk melanjutkan usahannya untuk berperilaku sesuai dengan harapan $^{21}$.

Konsistensi berarti tingkat keseragaman atau stabilitas. Peraturan, hukuman dan penghargaan yang konsisten membuat anak tidakbingung terhadap apa yang diharapkan dari mereka. Adabeberapa fungsi konsistensi yaitu : a) mempunyai nilai mendidik;b) mempunyai nilai motivasi yang kuat, c) mempertinggi penghargaan terhadap peraturan danorang yang berkuasa. Anak terus di beripendidikan disiplin yang konsisten cenderung lebih matang disiplin dirinya bila dibandingkan anak yang tidak diberi disiplin secara konsisten ${ }^{22}$.

Hurlock menyebutkan beberapa tipe-tipe disiplin yaitu: 1) Disiplin Otoriter; 2) Disiplin Permisif; 3) Disiplin demokrasi ${ }^{23}$.

${ }^{20}$ Apsari, F. (2013). Hubungan antara harga diri dan disiplin sekolah dengan perilaku bullying pada remaja (Doctoral dissertation, Universitas Muhammadiyah Surakarta).

21 Apsari, F. (2013). Hubungan antara harga diri dan disiplin sekolah dengan perilaku bullying pada remaja (Doctoral dissertation, Universitas Muhammadiyah Surakarta).

22 Apsari, F. (2013). Hubungan antara harga diri dan disiplin sekolah dengan perilaku bullying pada remaja (Doctoral dissertation, Universitas Muhammadiyah Surakarta).

${ }^{23}$ Handayani, N. T. (2018). "Peranan Orang Tua Dalam Meningkatkan Kedisiplinan Terhadap Perilaku Anak Di Masyarakat”(Studi Deskriptif Di Desa Kertamulya Kecamatan Padalarang) (Doctoral dissertation, FKIP UNPAS). 
Disiplin otoriter merupakan disiplin yang menggunakan peraturan dan pengaturann yang keras untuk memaksakan perilaku yang diinginkan. Disiplin otoriter selalu berarti mengendalikan melalui kekuatan eksternal dalam bentuk hukuman, terutama hukuman badan. Disiplin permisif berarti sedikit disiplin atau tidak berdisiplin. Disiplin permisif biasanya tidak membimbing anak kepola perilaku yang disetujui secara sosial dan tidak menggunakan hukuman. Disiplin demokrasi menggunakan penjelasan, diskusi dan penalaran untuk membantu anak mengerti mengapa perilaku tertentu diharapkan. Metode ini lebih menekankan aspek edukatif dari disiplin dari pada aspek dengan hukumannya. Disiplin demokrasi menggunakan hukuman dan penghargaan, dengan penekanan yang lebih besar pada penghargaan $^{24}$.

\section{Tata Tertib Sekolah}

Tata tertib adalah kumpulan aturan-aturan yang dibuat secara tertulis dan mengikat anggota masyarakat ${ }^{25}$. Sedangkan tata tertib sekolah adalah sejumlah peraturan yang harus ditaati atau dilaksanakan di sekolah, terutama demi kesuksesan proses belajar mengajar $^{26}$.

Tata tertib sekolah menurut Nawawi mencakup beberapa aspek, yaitu: 1) Tugas dan kewajiban, baik dalam kegiatan intra kulikuler maupun ekstra kurikuler; 2) Larangan-larangan bagi para siswa; 3) Sanksi-sanksi bagi para siswa ${ }^{27}$. Tata tertib sekolah bukan hanya sekedar kelengkapan dari sekolah, tetapi merupakan kebutuhan yang harus mendapat perhatian dari semua pihak yang terkait, terutama dari pelajar atau siswa itu sendiri. Sehubungan dengan hal tersebut, maka sekolah pada umumnya menyusun pedoman tata tertib

24 Aulina, C. N. (2013). Penanaman disiplin pada anak usia dini. PEDAGOGIA: Jurnal Pendidikan, 2(1), 36-49.

25 Arsaf, N. A. (2016). Faktor Penyebab Pelanggaran Tata Tertib (Studi Pada Siswa Di SMA Negeri 18 Makassar). JURNAL SOSIALISASI, 3(1).

26 Fitri, L. (2013). Penerapan Layanan Informasi Tentang Etika dan Disiplin di Sekolah untuk Mengurangi Pelanggaran Tata Tertib Pada Siswa SMP. Jurnal BK UNESA, 1(1).

27 Hadianti, L. S. (2017). Pengaruh Pelaksanaan Tata Tertib Sekolah Terhadap Kedisiplinan Belajar Siswa (Penelitian Deskriftif Analisis di SDN Sukakarya II Kecamatan samarang Kabupaten Garut). Jurnal Pendidikan UNIGA, 2(1), 1-8. 
sekolah bagi semua pihak yang terkait bagi gur, tenaga administrasi maupun siswa. Isi tata tertib sekolah secara garis besar adalah berupa tugas dankewajiban siswa yang harusdilakukan, larangan dan sanksi ${ }^{28}$.

Tata tertib sekolah baik yang berlaku umum maupun khusus meliputi tiga unsur, yakni: 1) Perbuatan atau tingkah lakuyang diharuskan dan dilarang; 2) Akibat atau sanksi yangmenjadi tanggung jawab pelaku atau pelanggar peraturan; 3) Cara atau prosedur untuk menyampaikan peraturan atau sujek yangdikenai tata tertib sekolah tersebut ${ }^{29}$.

Faktor-faktor dasar kepatuhan seseorang terhadap nilai tersebut, yaitu:

a. Normativist, biasanya kepatuhan kepada norma-norma hukum. Selanjutnya dikatakan bahwa kepatuhan ini terdapat dalam tiga bentuk, yaitu: 1) kepatuhan terhadap nilai atau norma itu sendiri; 2) kepatuhan pada proses tanpa memperdulikan normanya sendiri; 3 ) kepatuhan pada hasilnya/tujuan yang diharapkan dari peraturan itu.

b. Integralis, yaitu kepatuhan didasarkan pada kesadarandengan pertimbangan pertimbangan yang rasional

c. Fenomenalist, yaitu kepatuhan berdasarkan suara hati/sekedar basabasi

d. Hedonist, yaitu kepatuhan berdasarkan kepentingan sendiri ${ }^{30}$.

Menurut Rachman pentingnya disiplin bagi para siswa adalah sebagai berikut:

1. Memberikan dukungan bagi terciptanya perilaku yang tidak menyimpang.

2. Membantu siswa memahami danmenyesuaikan diridengan tuntutan lingkungan.

3. Cara menyelesaikan tuntutan yang ingin ditujukan pesertadidiknya terhadap lingkungan.

${ }^{28}$ Anggraini, E. N., \& Subadi, T. (2016). Pengelolaan Tata Tertib Sekolah Menengah Pertama. Jurnal VARIDIKA, 27(2), 144-151.

${ }^{29}$ Hadianti, L. S. (2017). Pengaruh Pelaksanaan Tata Tertib Sekolah Terhadap Kedisiplinan Belajar Siswa (Penelitian Deskriftif Analisis di SDN Sukakarya II Kecamatan samarang Kabupaten Garut). Jurnal Pendidikan UNIGA, 2(1), 1-8.

${ }^{30}$ Hadianti, L. S. (2017). Pengaruh Pelaksanaan Tata Tertib Sekolah Terhadap Kedisiplinan Belajar Siswa (Penelitian Deskriftif Analisis di SDN Sukakarya II Kecamatan samarang Kabupaten Garut). Jurnal Pendidikan UNIGA, 2(1), 1-8. 
4. Untuk mengatur keseimbangan keinginan individu satu dengan indivu lainnya.

5. Menjauhi siswa melakukan hal yang baik danbenar.

6. Mendorong siswa melakukan hal-hal yang baik danbenar.

7. Peserta didik belajar dan bermanfaat baginya dan lingkungannya.

8. Kebiasaan baik itu menyebabkan keterangan jiwanya dan lingkungan ${ }^{31}$.

Faktor-faktor yang memengaruhi tata tertib sekolah adalah: 1)

Faktor lingkungan keluarga; 2) Faktor lingkungan sekolah; 3) Faktor lingkungan masyarakat ${ }^{32}$. Tata tertib sekolah bertujuan agar semua siswa sekolah mengetahui apa tugas, hak, dan kewajiban serta melaksanakan dengan baik sehingga kegiatan sekolah dapat dapar berjalan dengan lancar. Prinsip tata sekolah adalah diharuskan, diajukan, dan ada yang tidak boleh dilakukan dalam pergaulan di lingkungan sekolah ${ }^{33}$.

Pendidikan dalam sekolah tidak akan pernah lepas dengan peserta didik atau siswa. Dalam menjalankan fungsinya sebagai manusia pembelajar dan menaati seluruh aturan yang diberlakukan dalam sekolah tentunya harus menjadi perhatian utama dalam melaksanakan sebuah proses pedidikan yang lebih manusiawi. Sebagaimana dalam UU No 20 Tahun 2003 menjelaskan tentang defenisi peserta didik sebagai berikut:

Peserta didik adalah anggota masyarakat yang berusaha mengembangkan potensi diri melalui proses pembelajaran yang tersedia pada jalur, jenjang, dan jenis pendidikan tertentu. Fungsi siswa dalam pelakasanaan tata tertib sekolah menjadi hal yang prioritas bagi sebagai beban moral yang harus dipatuhi dalam menciptakan suasana ketertiban dalam belajar baik didalam kelasa maupun diluar kelas ${ }^{34}$.

${ }^{31}$ Yuliastuti, Y., \& Vebrianto, R. (2019). Pengaruh Lingkungan Negatif Terhadap Kedisiplinan Siswa SD Negeri 134 Pekanbaru. Journal of Natural Science and Integration, 1(2), 221-227.

32 Yuliastuti, Y., \& Vebrianto, R. (2019). Pengaruh Lingkungan Negatif Terhadap Kedisiplinan Siswa SD Negeri 134 Pekanbaru. Journal of Natural Science and Integration, 1(2), 221-227.

33 Angranti, W. (2018). Pelaksanaan Tata Tertib Sekolah Oleh Siswa. Media Ilmu, 2(2), 1-12.

${ }^{34}$ Irwansa, A., \& MAF'UL, M. A. (2016). Analisis Pelaksanaan Tata Tertib Sekolah pada Siswa di SMK Negeri 1 Makassar. Jurnal Tomalebbi, 2(1), 1-13. 


\section{Metode}

Pada penelitian ini, metode yang digunakan adalah deskriptif kualitatif, yaitu suatu metode yang bertujuan menggambarkan bagaimana keadaan dan fenomena yang sebenarnya, kemudian dideskripsikan ke dalam laporan penelitian. Metode kualitatif merupakan suatu proses penelitian yang dilakukan secara wajar dan natural sesuai dengan kondisi objektif di lapangan tanpa adanya manipulasi, serta jenis data yang dikumpulkan ${ }^{35}$. Pengumpulan data dilakukan dilakukan melalui wawancara, observasi dan dokumentasi ${ }^{36}$. Teknik analisis data melalui proses reduksi, display, dan verifikasi ${ }^{37}$. Pengujian keabsahan data dilakukan melalui member check, perpanjangan pengamatan, dan peningkatan ketekunan ${ }^{38}$.

\section{Hasil dan Pembahasan}

\section{Penerapan tata tertib sekolah : Sebuah Langkah Strategis}

Sebagai sekolah yang terhitung baru di Kabupaten Konawe, SMA Negeri 1 Konawe menghadapi tantangan yang tidak kecil dalam pengelolaan sekolah ${ }^{39}$. Tidak hanya dalam pengembangan guru dan tenaga kependidikan. Lebih penting lagi adalah mengelola peserta didik agar dapat merasakan layanan pendidikan dan pembelajaran yang berkualitas. Problem yang dihadapi oleh sekolah terkait dengan peserta didik adalah kesulitan peserta didik untuk beradaptasi dengan berbagai kegiatan-kegiatan sekolah, terutama kegiatan pembelajaran.

Kondisi lingkungan sekolah menjadi daya tarik beberapa siswa meninggalkan jam pelajaran, misalnya bermain di kebun masyarakat. Bagi masyarakat, perilaku ini meresahkan. Selain itu, jika ditelusuri pada kondisi keluarga, terlihat bahwa kondisi keluarga peserta didik masih dalam tahap membangun kesadaran tentang pendidikan. Prinsip yang mereka pegang adalah "yang penting sekolah", yang berarti bahwa peserta didik diserahkan sepenuhnya dalam tanggung jawab

\footnotetext{
${ }^{35}$ Bungin, B. (2007). Penelitian kualitatif: komunikasi, ekonomi, kebijakan publik, dan ilmu sosial lainnya. Kencana.

36 Moleong, L. J. (2007). Metodologi penelitian kualitatif edisi revisi. Bandung: PT Remaja Rosdakarya, 103.

37 Miles, M. B. D. A. (1992). A Michael Huberman. Analisis Data Kualitatif: Buku Sumber Tentang Metode-metode Baru.

${ }^{38}$ Sugiyono, P. (2005). Memahami penelitian kualitatif. Bandung: Alfabeta. Kabupaten Konawe.

39 Berdiri tahun 2007, sebagai hasil dari pemekaran kecamatan di
} 
sekolah. Sementara itu, idealnya keluarga adalah sekolah pertama bagi seorang anak. Hasil riset menunjukkan bahwa lingkugan pendidikan memengaruhi pendidikan karakter peserta didik ${ }^{40}$, juga minat belajar $^{41}$. Selain itu, lingkungan keluarga berperan penting dalam perbaikan hasil belajar ${ }^{42}$ dan pergaulan sosial peserta didik ${ }^{43}$.

Karenya penerapan tata tertib sekolah merupakan langkah strategis yang diambil sebagai panduan warga sekolah dalam berperilaku di lingkungan sekolah, karena terkait dengan berbagai aspek perkembangan peserta didik, seperti minat belajar, prestasi, dan kemampuan bermasyarakat.

\section{Kedisiplinan siswa: Cermin Karakteristik Sosial}

Sebelum berdirinya SMA Negeri 1 Konawe, masyarakat umumnya menyekolahkan anak-anak mereka di SMA Negeri Wawotobi, Madrasah Aliyah Al Ikhlas Wawotobi, SMA Nasional Wawotobi, dan SMEA Wonua Mandara. Belakangan berdiri pula SMA Cendekia. Wawotobi sebagai pusat ibukota kecamatan saat itu menjadi destinasi pendidikan dari berbagai desa. Dalam kondisi demikian, akses masyarakat sangat terbatas terhadap pendidikan karena masih tertuju ke Wawotobi. Hasilnya, banyak lulusan SMP yang memutuskan untuk bekerja, merantau, atau menjadi petani di sawah dan ladang orang tua. Ketika pemekaran kecamatan terjadi, akibat bawaannya adalah pendirian sekolah, salah satunya SMA Negeri 1 Konawe di Kecamatan Konawe. Kehadiran sekolah ini menjadi jawaban atas rendahnya akses pendidikan masyarakat, akibat daya tampung sekolah yang terbatas. Meskipun demikian, karakteristik masyarakat masih sangat "sederhana" memandang fungsi

${ }^{40}$ Ramdhani, M. A. (2017). Lingkungan Pendidikan dalam Implementasi Pendidikan Karakter. Jurnal Pendidikan UNIGA, 8(1), 28-37.

41 Roza, N. (2015). Pengaruh Lingkungan Pendidikan Terhadap Minat Belajar Bahasa Arap Siswa Kelas VIII MtsN Wonokromo, Bantul, Yogyakarta Tahun Ajaran 2014/2015. Skripsi. Universitas Islam Negeri Sunan Kalijaga Yogyakarta.

${ }^{42}$ Sudikno, I. S. (2014). Pengaruh Lingkungan Keluarga, Lingkungan Sekolah, Disiplin Belajar dan Motivasi Belajar terhadap Prestasi Belajar Ekonomi Siswa SMA Kelas XI IPS SMA PGRI 1 Taman Pemalang. Economic Education Analysis Journal, 3(1).

${ }^{43}$ Saputro, H., \& Talan, Y. O. (2017). Pengaruh Lingkungan Keluarga Terhadap Perkembangan Psikososial Pada Anak Prasekolah. Journal Of Nursing Practice, 1(1), 1-8. 
lembaga pendidikan, menyebabkan persoalan peserta didik menjadi tantangan sendiri. Kehadiran sekolah di kecamatan Konawe belum diiringi kesiapan mental masyarakat untuk beradaptasi, terutama dengan lingkungan sekolah. Sehingga perilaku siswa di sekolah masih menggambarkan perilaku bawaan dari rumah atau lingkungan sosialnya. Hasil riset sebelumnya menunjukkan bahwa persoalan lingkungan sosial menjadi penyumbang dalam perilaku peserta didik $^{44}$. Kedisiplinan siswa di SMA Negeri 1 Konawe menunjukkan kecenderungan yang bervariasi, disebabkan oleh kondisi lingkungan sekolah dan variasi latar belakang siswa.

\section{Strategi penerapan tata tertib sekolah: Memberdayakan Potensi Sosial}

Menanamkan disiplin siswa melalui penerapan tata tertib sekolah tidak dapat dilakukan dengan hanya mengandalkan kekuasaan kepala sekolah semata. Sebagai sebuah langkah stategis, maka diperlukan keterlibatan berbagai elemen yang terkait langsung dengan kepentingan sekolah. Karenanya strategi penerapan tata tertib sekolah dilakukan dengan sosialisasi pada orang tua murid dan masyarakat, melibatkan organisasi siswa intra sekolah (OSIS), gerakan pramuka, serta menggiatkan perkumpulan olah raga siswa.

Hasil-hasil riset menunjukkan bahwa pemberdayaan potensipotensi sosial, sangat membantu dalam peningkatan mutu pendidikan $^{45}$, kesuksesan kebijakan gerakan literasi ${ }^{46}$, dan kegiatan sekolah secara keseluruhan ${ }^{47}$. Menyusun langkah stategis dalam mendisiplinkan siswa dapat dilihat sebagai komitmen sekolah dalam menjaga hubungan dengan masyarakat (orang tua peserta didik) sebagai pelanggan sekolah ${ }^{48}$.

${ }^{44}$ Sutrisno, H. (2009). Kasus perilaku pelanggaran disiplin siswa di sekolah ditinjau dari kerangka teori sosiologi fungsionalisme. Jurnal Pendidikan Inovatif, 4(2), 60-66.

45 Saifulloh, M., Muhibbin, Z., \& Hermanto, H. (2012). Strategi Peningkatan Mutu Pendidikan Di Sekolah. Jurnal Sosial Humaniora, 5(2), 206-218.

${ }^{46}$ Wulandari, R. (2017). Implementasi Kebijakan Gerakan Literasi Sekolah di Sekolah Dasar Islam Terpadu Lukman AL Hakim Internasional. Spektrum Analisis Kebijakan Pendidikan, 6(3), 319-330.

${ }^{47}$ DI TK, K. W. Y., \& DINI, J. P. A. U. (2016). Pelibatan Orang Tua Dalam Program Sekolah.

48 Siregar, F. A. (2019). Mengelola Hubungan Sekolah Dengan Masyarakat. IJTIMAIYAH Jurnal Ilmu Sosial dan Budaya, 2(2). 


\section{Kesimpulan}

Berdasarkan hasil dan pembahasan penelitian dapat disimpulkan bahwa penerapan tata tertib merupakan langkah strategis yang mesti diambil oleh sekolah. Praktik yang ditunjukkan di SMA Negeri 1 Konawe dapat menjadi inspirasi bagi sekolah-sekolah lainnya, terutama terkait dengan pembinaan disiplin siswa. Kondisi kedisiplinan siswa di setiap sekolah cenderung bervariasi, tetapi dengan penerapan tata tertib secara efektif dan humanis, maka kecenderungan disiplin siswa yang rendah dapat diperbaiki. Selain itu, penerapan tata tertib tidak hanya menjadi domain pimpinan sekolah dan guru, tetapi merupakan kolaborasi dengan siswa, orang tua, dan masyarakat. 


\section{Daftar Pustaka}

Anggraini, E. N., \& Subadi, T. (2016). Pengelolaan Tata Tertib Sekolah Menengah Pertama. Jurnal VARIDIKA, 27(2), 144151.

Angranti, W. (2018). Pelaksanaan Tata Tertib Sekolah Oleh Siswa. Media Ilmu, 2(2), 1-12.

Apsari, F. (2013). Hubungan antara harga diri dan disiplin sekolah dengan perilaku bullying pada remaja (Doctoral dissertation, Universitas Muhammadiyah Surakarta).

Ardini, P. P. (2015). "Penerapan Hukuman", Bias Antara Upaya Menanamkan Disiplin Dengan Melakukan Kekerasan Terhadap Anak. Jurnal Pendidikan Usia Dini, 9(2), 251-266.

Ariananda, E. S., Hasan, S., \& Rakhman, M. (2014). Pengaruh kedisiplinan siswa di sekolah terhadap prestasi belajar siswa teknik pendingin. Journal of Mechanical Engineering Education, 1(2), 233-238.

Arsaf, N. A. (2016). Faktor Penyebab Pelanggaran Tata Tertib (Studi Pada Siswa Di SMA Negeri 18 Makassar). JURNAL SOSIALISASI, 3(1).

Aulina, C. N. (2013). Penanaman disiplin pada anak usia dini. PEDAGOGIA: Jurnal Pendidikan, 2(1), 36-49.

Bungin, B. (2007). Penelitian kualitatif: komunikasi, ekonomi, kebijakan publik, dan ilmu sosial lainnya. Kencana.

DI TK, K. W. Y., \& DINI, J. P. A. U. (2016). Pelibatan Orang Tua Dalam Program Sekolah.

Fitri, L. (2013). Penerapan Layanan Informasi Tentang Etika dan Disiplin di Sekolah untuk Mengurangi Pelanggaran Tata Tertib Pada Siswa SMP. Jurnal BK UNESA, 1(1).

Hadianti, L. S. (2017). Pengaruh Pelaksanaan Tata Tertib Sekolah Terhadap Kedisiplinan Belajar Siswa (Penelitian Deskriftif Analisis di SDN Sukakarya II Kecamatan samarang Kabupaten Garut). Jurnal Pendidikan UNIGA, 2(1), 1-8.

Handayani, N. T. (2018). "Peranan Orang Tua Dalam Meningkatkan Kedisiplinan Terhadap Perilaku Anak Di Masyarakat”(Studi Deskriptif Di Desa Kertamulya Kecamatan Padalarang) (Doctoral dissertation, FKIP UNPAS).

Hendra, V. (2018). Peran Orang Tua Dalam Menerapkan Kasih Dan Disiplin Kepada Anak Usia 2-6 Tahun Sebagai Upaya 
Pembentukkan Karakter. KURIOS (Jurnal Teologi dan Pendidikan Agama Kristen), 3(1), 48-65.

Indonesia, U. U. R. (2003). Sistem pendidikan nasional. Jakarta: Direktorat Pendidikan Menengah Umum.

Indonesia, P. R. (2006). Undang-undang Republik Indonesia nomor 20 tahun 2003 tentang sistem pendidikan nasional.

Indonesia, P. R. (2006). Undang-undang Republik Indonesia nomor 20 tahun 2003 tentang sistem pendidikan nasional.

Irwansa, A., \& MAF'UL, M. A. (2016). Analisis Pelaksanaan Tata Tertib Sekolah pada Siswa di SMK Negeri 1 Makassar. Jurnal Tomalebbi, 2(1), 1-13.

Miles, M. B. D. A. (1992). A Michael Huberman. Analisis Data Kualitatif: Buku Sumber Tentang Metode-metode Baru.

Moleong, L. J. (2007). Metodologi penelitian kualitatif edisi revisi. Bandung: PT Remaja Rosdakarya, 103.

Nansi, D., \& Utami, F. T. (2016). Hubungan antara Regulasi Emosi dengan Perilaku Disiplin Santri Madrasah Aliyah Pondok Pesantren Qodratullah Langkan. Psikis: Jurnal Psikologi Islami, 2(1).

Ningsih, B. M., \& Widiharto, C. A. (2014). Peningkatan Disiplin Siswa dengan Layanan Informasi Media Film. EMPATI-Jurnal Bimbingan dan Konseling, 1(1/oktober).

Lomu, L., \& Widodo, S. A. (2018, February). Pengaruh Motivasi Belajar dan Disiplin Belajar terhadap Prestasi Belajar Matematika Siswa. In Prosiding Seminar Nasional Pendidikan Matematika Etnomatnesia.

Prasetyo, P. E. (2008). Pengaruh disiplin siswa dan fasilitas perpustakaan sekolah terhadap prestasi belajar siswa mata pelajaran ekonomi. Dinamika Pendidikan, 3(2).

Ramdhani, M. A. (2017). Lingkungan Pendidikan dalam Implementasi Pendidikan Karakter. Jurnal Pendidikan UNIGA, 8(1), 28-37.

Roshita, I. (2014). Meningkatkan Kedisiplinan Siswa Melalui Layanan Bimbingan Kelompok dengan Teknik Modeling. Jurnal Penelitian Tindakan Kelas, 15(4).

Saifulloh, M., Muhibbin, Z., \& Hermanto, H. (2012). Strategi Peningkatan Mutu Pendidikan Di Sekolah. Jurnal Sosial Humaniora, 5(2), 206-218. 
Siregar, F. A. (2019). Mengelola Hubungan Sekolah Dengan Masyarakat. IJTIMAIYAH Jurnal Ilmu Sosial dan Budaya, 2(2).

Sudikno, I. S. (2014). Pengaruh Lingkungan Keluarga, Lingkungan Sekolah, Disiplin Belajar dan Motivasi Belajar terhadap Prestasi Belajar Ekonomi Siswa SMA Kelas XI IPS SMA PGRI 1 Taman Pemalang. Economic Education Analysis Journal, 3(1).

Sugiyono, P. (2005). Memahami penelitian kualitatif. Bandung: Alfabeta.

Sutrisno, H. (2009). Kasus perilaku pelanggaran disiplin siswa di sekolah ditinjau dari kerangka teori sosiologi fungsionalisme. Jurnal Pendidikan Inovatif, 4(2), 60-66.

Trisnawati, D. D. (2013). Membangun Disiplin dan Tanggung Jawab Siswa SMA Khadijah Surabaya melalui Implementasi Tata Tertib Sekolah. Kajian Moral dan Kewarganegaraan, 2(1), 397-411.

Wulandari, R. (2017). Implementasi Kebijakan Gerakan Literasi Sekolah di Sekolah Dasar Islam Terpadu Lukman AL Hakim Internasional. Spektrum Analisis Kebijakan Pendidikan, 6(3), 319-330.

Yuliastuti, Y., \& Vebrianto, R. (2019). Pengaruh Lingkungan Negatif Terhadap Kedisiplinan Siswa SD Negeri 134 Pekanbaru. Journal of Natural Science and Integration, 1(2), 221-227. 